\title{
Diversity and aggregation areas of planktonic cnidarians of the southern channels of Chile (Boca del Guafo to Pulluche Channel)
}

\author{
Sergio Palma ${ }^{1}$, Pedro Apablaza ${ }^{1}$ \& Daniela Soto ${ }^{1}$ \\ ${ }^{1}$ Escuela de Ciencias del Mar, Pontificia Universidad Católica de Valparaíso \\ Casilla 1020, Valparaíso, Chile
}

\begin{abstract}
We identified 36 species of cnidarians (27 hydromedusae, 9 siphonophores) collected from the Moraleda, King, Darwin, and Pulluche channels, located in southern Chile. The hydromedusae Gossea brachymera, Hybocodon unicus, and Sarsia coccometra, and the siphonophores Rosacea cymbiformis and R. plicata were recorded for the first time in the southern channels. Diversity values were higher for Hydromedusae (2.66 bits) than for Siphonophorae (1.15 bits). The largest aggregates were found in the Moraleda and Pulluche channels, with densities that exceeded 7,000 ind $1000 \mathrm{~m}^{-3}$. The vertical distribution of the dominant species showed Solmundella bitentaculata to be located near the surface (0-20 m), whereas Sphaeronectes gracilis, Muggiaea atlantica, Clytia simplex, and Proboscidactyla ornata were found in subsurface waters $(20-50 \mathrm{~m})$ and Amphogona apicata in deeper waters $(50-100 \mathrm{~m})$. According to the Pearson analysis, salinity correlated positively with $S$. gracilis and $S$. bitentaculata and negatively with P. ornata. C. simplex was indirectly associated with temperature and the dissolved oxygen concentration.
\end{abstract}

Key words: cnidarians, gelatinous zooplankton, distribution, diversity, southern channels, Chile.

\section{Diversidad y áreas de agregación de los cnidarios planctónicos en los canales del sur de Chile (Boca del Guafo a Canal Pulluche)}

RESUMEN. Se identificaron 36 especies de cnidarios, 27 hidromedusas y 9 sifonóforos, colectadas en los canales Moraleda, King, Darwin y Pulluche, localizados en aguas interiores del sur de Chile. Las hidromedusas Gossea brachymera, Hybocodon unicus, Sarsia coccometra, y los sifonóforos Rosacea cymbiformis y R. plicata se registraron por primera vez en los canales australes. Los valores de diversidad fueron más altos en hidromedusas que en sifonóforos, con una media de 2,66 y 1,15 bits, respectivamente. Las mayores agregaciones se determinaron en el canal Moraleda y canal Pulluche, con densidades superiores a 7.000 ind $1000 \mathrm{~m}^{-3}$. La distribución vertical de las especies dominantes mostró que Solmundella bitentaculata fue más superficial (0-20 m); Sphaeronectes gracilis, Muggiaea atlantica, Clytia simplex y Proboscidactyla ornata fueron subsuperficiales $(20-50 \mathrm{~m})$ y Amphogona apicata más profunda (50-100 m). El análisis de Pearson indicó que la abundancia de $S$. gracilis y $S$. bitentaculata se correlacionó positivamente con la salinidad, mientras que para $P$. ornata fue negativa. En cambio, $C$. simplex se asoció indirectamente con la temperatura y la concentración de oxígeno disuelto.

Palabras clave: cnidarios, zooplancton gelatinoso, distribución, diversidad, canales australes, Chile.

Corresponding author: spalma@ucv.cl

\section{INTRODUCTION}

In recent years, strong and sustained increments of gelatinous organism populations have been recorded in different geographic marine areas (Mills, 2001; Brodeur et al., 2002). These proliferations have caused important changes in the pelagic community structure due to the impact of gelatinous organisms as consumers and competitors of zooplankton and fish larvae (Matsakis \& Conover, 1991; Purcell, 1997). For example, in the Bering Sea, the biomass of the medusa Chrysaora melenaster increased over 10 times between 1980 and 1990, affecting the commercial fish stock (Mills, 2001). 
In the waters of the Humboldt Current System, gelatinous organisms such as medusae, siphonophores, and ctenophores are very abundant and dense aggregates have been recorded in coastal upwelling areas during the warm periods of the year (Palma \& Rosales, 1995; Palma \& Apablaza, 2004). These organisms can have a strong trophic impact. For example, the siphonophore Bassia bassensis is estimated to be able to remove up to $17 \%$ of the copepod biomass off the Antofagasta peninsula (Pagès et al., 2001).

Chile's interior waters stretch from Puerto Montt to Cape Horn and include some 84,000 km of coastline. This zone has a complex topography and is marked by the seasonality of its oceanographic characteristics. Exterior waters from the adjacent Pacific are constantly entering the area and mixing with the less salty waters coming from fluvial contributions, pluviosity, and glacial melting (Palma \& Silva, 2004; Silva \& Palma, 2006). This continual exchange favors the presence of planktonic species from different biogeographic origins in the interior waters (Palma \& Silva, 2004; Palma, 2006).

Fifty species of planktonic cnidarians have been recorded in this extensive zone: 43 hydromedusae and 14 siphonophores (Galea, 2006; Galea et al., 2007; Palma, 2006; Palma et al., 2007). The siphonophore were recorded between Puerto Montt and Cape Horn, whereas the hydromedusae were found in three restricted areas of the southern region: Comau Fjord (42²0'S) (Galea, 2006; Galea et al., 2007), the area between Boca del Guafo and Elefantes Estuary (Palma et al., 2007), and the Strait of Magellan and adjacent channels (53-55 ${ }^{\circ}$ ) (Pagès \& Orejas, 1999).

From early in the 1990s, the northern sector of interior waters (Chiloé Island and adjacent areas) has been subjected to intense marine farming of algae, mollusks, and fish, particularly salmon, whose production in 2005 was 398,909 tons (SERNAPESCA, 2007). From February to June 2002, the farming facilities in this sector were negatively affected by proliferations of hydromedusae (Aequorea macrodactyla) and scyphomedusae (Chrysaora plocamia and Phacellophora camtschatica), which caused salmon mortalities at a variety of farming centers (unpublished data).

Given the importance of the cnidarians in marine ecosystems, the present work analyzes the taxonomic composition, diversity, vertical distribution, and geographic distribution of planktonic cnidarians in order to determine their main areas of aggregations in the interior waters of the channel sector in southern Chile. Moreover, the results for hydromedusae are compared with those obtained in the same study area in the spring of 2002 (Palma et al., 2007).

\section{MATERIALS AND METHODS}

During the CIMAR 9 Fiordos cruise, carried out between 6 and 18 November 2003, 17 oceanographic stations were sampled along the Moraleda, Ninualac, Darwin, Pulluche, and Chacabuco channels (44 ${ }^{\circ} 13^{\prime}-$ $45^{\circ} 47^{\prime}$ S) (Fig. 1). At each station, oblique tows for zooplankton were done at depths of 0-20, 20-50, 50-100, and 100-150 m using and opening-closing Tucker trawl ( $1 \mathrm{~m}^{2}$ mouth), equipped with three 300 $\mu \mathrm{m}$ mesh nets and a flowmeter mounted in the frame. The samples were obtained mostly during the day (14 stations) and were placed in sea water with 5\% borax-neutralized formalin.

The medusae and siphonophores (including polygastric and eudoxid stages) were identified using specialized literature (Totton, 1965; Kramp, 1968; Bouillon \& Boero, 2000). Later, the geographic distribution of the dominant species (abundance $>$ $5 \%$ of all analyzed specimens) was determined. The abundance was standardized in ind $1000 \mathrm{~m}^{-3}$ and the vertical distribution was calculated considering the percentage of individuals per stratum with respect to the total number of specimens in the water column. Moreover, the Shannon-Wiener index was calculated to estimate the species diversity.

As cnidarians are distributed in both shallow and deep strata, weighted averages were determined for the oceanographic parameters in the water column from the surface to $150 \mathrm{~m}$ depth. These values were used with the Pearson index to estimate the correlation between the abundance of the dominant species and the weighted averages of temperature, salinity, and dissolved oxygen.

\section{RESULTS}

\section{Species composition}

A total of 36 planktonic cnidarian species were determined, corresponding to 27 hydromedusae and nine siphonophores (Table 1). The hydromedusae Gossea brachymera, Hybocodon unicus, and Sarsia coccometra and the siphonophores Rosacea cymbiformis 


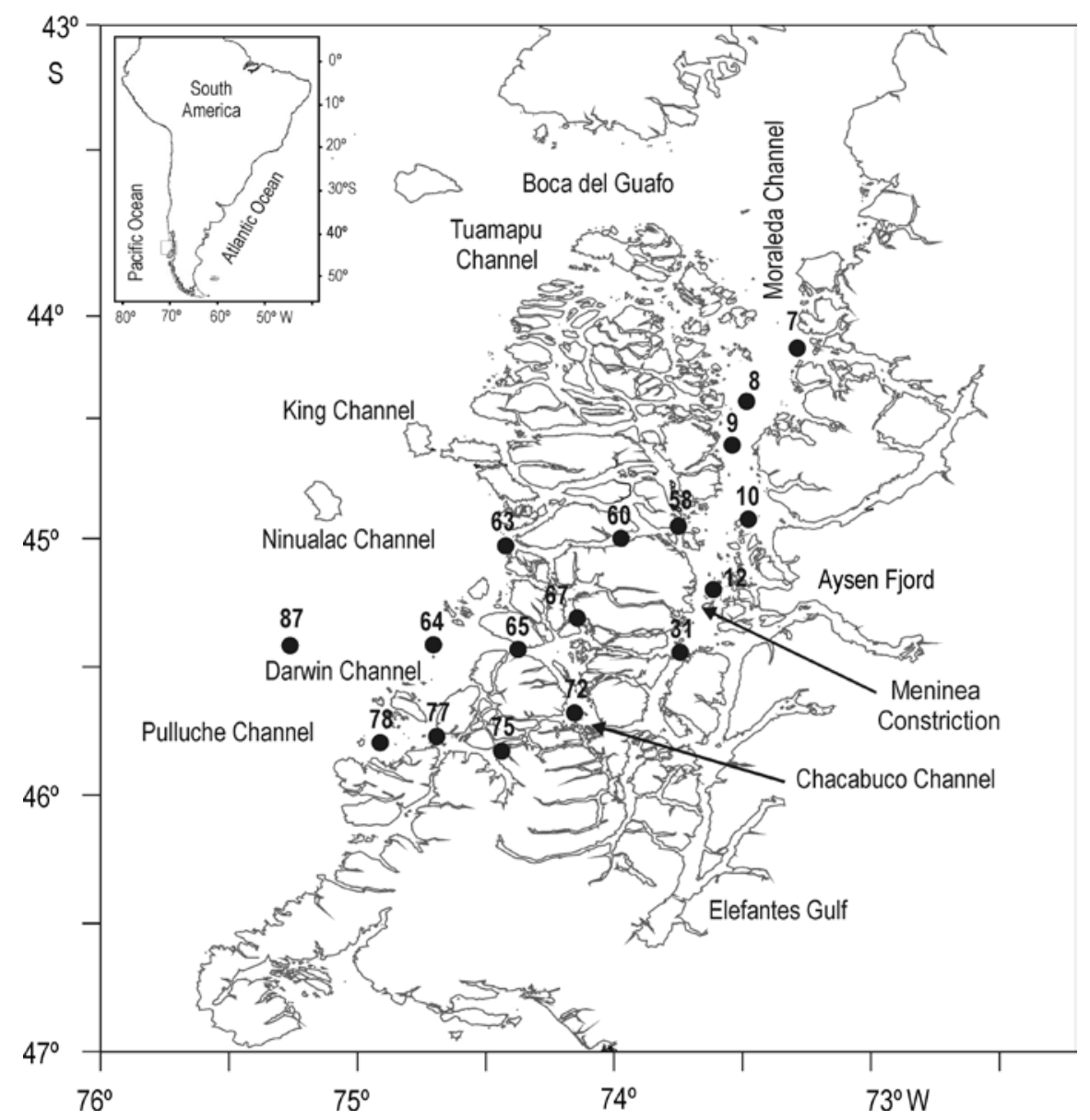

Figure 1. Location of zooplankton sampling stations between the Boca del Guafo to Pulluche Channel.

and $R$. plicata were recorded for the first time in the interior waters of southern Chile. The dominant species were Sphaeronectes gracilis (28.6\%), Muggiaea atlantica (24.4\%), Clytia simplex (9.6\%), Proboscidactyla ornata (7.1\%), Amphogona apicata (6.1\%), and Solmundella bitentaculata (5.1\%); these made up $81 \%$ of the analyzed organisms (Table 1). The most frequent species were Clytia simplex, Bougainvillia sp., Hydractinia borealis, Proboscidactyla ornata, Sphaeronectes gracilis, and Muggiaea atlantica, which were caught at $100 \%$ of the stations. With respect to the eudoxid stage, the peak abundances corresponded to $M$. atlantica (89.6\%), S. gracilis $(5.7 \%)$, and L. conoidea (4.1\%) (Table 1).

\section{Species diversity}

The diversity values were quite different for hydromedusae and siphonophores, which averaged 2.66 and 1.15 bits, respectively (Fig. 2). The hydromedusae values fluctuated between 1.24 and 3.41 bits. The minimum values were found at the eastern end of the oceanic channels and at the oceanic station (Sta. 87), whereas the maxima were found in the Moraleda and Ninualac channels. For siphonophores, the values were much lower, fluctuating between 0.20 and 1.75 bits, with low values predominating throughout the study area except for some high-diversity cores (1.501.75 bits) found at stations 31,58 , and 75 .

\section{Spatial distribution}

The density of individuals per station was highly variable and fluctuated between 2,114 and 30,518 ind $\cdot 1000 \mathrm{~m}^{-3}$ at stations 58 (Ninualac Channel) and 87 (oceanic), averaging 7,845 $\pm 7,400$ ind $1000 \mathrm{~m}^{-3}$ (Fig. 3a). The lowest densities $\left(<3,000\right.$ ind $\left.\cdot 1000 \mathrm{~m}^{-3}\right)$ were found in the Ninualac and Darwin channels, 
Table 1. Mean abundance, standard deviation, total abundance and percentage of hydromedusae and siphonophores collected in the study area. ne: nectophores, eu: eudoxids.

\begin{tabular}{|c|c|c|c|c|c|}
\hline Species & & $\begin{array}{c}\text { Average } \\
\text { (ind } \cdot 1000 \mathrm{~m}^{-3} \text { ) }\end{array}$ & $\begin{array}{l}\text { Standard } \\
\text { deviation }\end{array}$ & $\begin{array}{l}\text { Total abundance } \\
\text { (ind } \cdot 1000 \mathrm{~m}^{-3} \text { ) }\end{array}$ & $\begin{array}{c}\text { Dominance } \\
(\%)\end{array}$ \\
\hline Hydromedusae & & & & 53.899 & 24.98 \\
\hline Clytia simplex & & 699 & 548 & 11.887 & 8.91 \\
\hline Proboscidactyla ornata & & 527 & 593 & 8.966 & 6.72 \\
\hline Amphogona apicata & & 441 & 1.350 & 7.495 & 5.62 \\
\hline Solmundella bitentaculata & & 381 & 1.017 & 6.474 & 4.85 \\
\hline Proboscidactyla stellata & & 196 & 284 & 3.331 & 2.50 \\
\hline Euphysa aurata & & 178 & 196 & 3.029 & 2.27 \\
\hline Hydractinia borealis & & 163 & 129 & 2.779 & 2.08 \\
\hline Bougainvillia muscoides & & 108 & 107 & 1.836 & 1.37 \\
\hline Hybocodon unicus & & 90 & 95 & 1.530 & 1.15 \\
\hline Bougainvillia sp. & & 81 & 88 & 1.376 & 1.03 \\
\hline Ectopleura dumortieri & & 64 & 135 & 1.082 & 0.81 \\
\hline Liriope tetraphylla & & 55 & 116 & 938 & 0.70 \\
\hline Proboscidactyla sp. & & 39 & 52 & 667 & 0.50 \\
\hline Hydractinia minuta & & 26 & 38 & 443 & 0.33 \\
\hline Leuckartiara octona & & 22 & 31 & 396 & 0.28 \\
\hline Rophalonema velatum & & 21 & 35 & 355 & 0.27 \\
\hline Obelia spp. & & 20 & 53 & 341 & 0.26 \\
\hline Halopsis ocellata & & 17 & 23 & 297 & 0.22 \\
\hline Phialella quadrata & & 14 & 47 & 239 & 0.18 \\
\hline Proboscidactyla mutabilis & & 6 & 14 & 110 & 0.08 \\
\hline Cunina sp. & & 4 & 9 & 75 & 0.06 \\
\hline Sarsia coccometra & & 5 & 8 & 82 & 0.06 \\
\hline Gossea brachymera & & 4 & 8 & 68 & 0.05 \\
\hline Sarsia eximia & & 3 & 8 & 47 & 0.04 \\
\hline Bougainvillia pyramidata & & 2 & 5 & 32 & 0.02 \\
\hline Cunina peregrina & & 1 & 3 & 18 & 0.01 \\
\hline Calycopsis sp. & & 0 & 2 & 7 & 0.00 \\
\hline Siphonophorae & & & & 161.912 & 75.02 \\
\hline \multirow[t]{2}{*}{ Sphaeronectes gracilis } & ne & 2.145 & 3.593 & 36.464 & 27.34 \\
\hline & $\mathrm{eu}$ & 279 & 517 & 4.745 & \\
\hline \multirow[t]{2}{*}{ Muggiaea atlantica } & ne & 1.813 & 2.696 & 30.818 & 23.11 \\
\hline & $\mathrm{eu}$ & 4.388 & 4.718 & 74.581 & \\
\hline Pyrostephos vanhoeffeni & ne & 547 & 1.830 & 9.291 & 6.97 \\
\hline \multirow[t]{2}{*}{ Lensia conoidea } & ne & 100 & 248 & 1.700 & 1.27 \\
\hline & $\mathrm{eu}$ & 201 & 502 & 3.411 & \\
\hline \multirow[t]{2}{*}{ Dimophyes arctica } & ne & 13 & 49 & 228 & 0.17 \\
\hline & $\mathrm{eu}$ & 15 & 44 & 261 & \\
\hline \multirow[t]{2}{*}{ Eudoxoides spiralis } & ne & 11 & 30 & 187 & 0.14 \\
\hline & $\mathrm{eu}$ & 6 & 17 & 110 & \\
\hline Sphaeronectes fragilis & ne & 6 & 9 & 99 & 0.07 \\
\hline Rosacea plicata & ne & 1 & 2 & 10 & 0.01 \\
\hline Rosacea cymbiformis & ne & 0 & 2 & 7 & 0.00 \\
\hline Total & & & & 215.812 & 100 \\
\hline
\end{tabular}



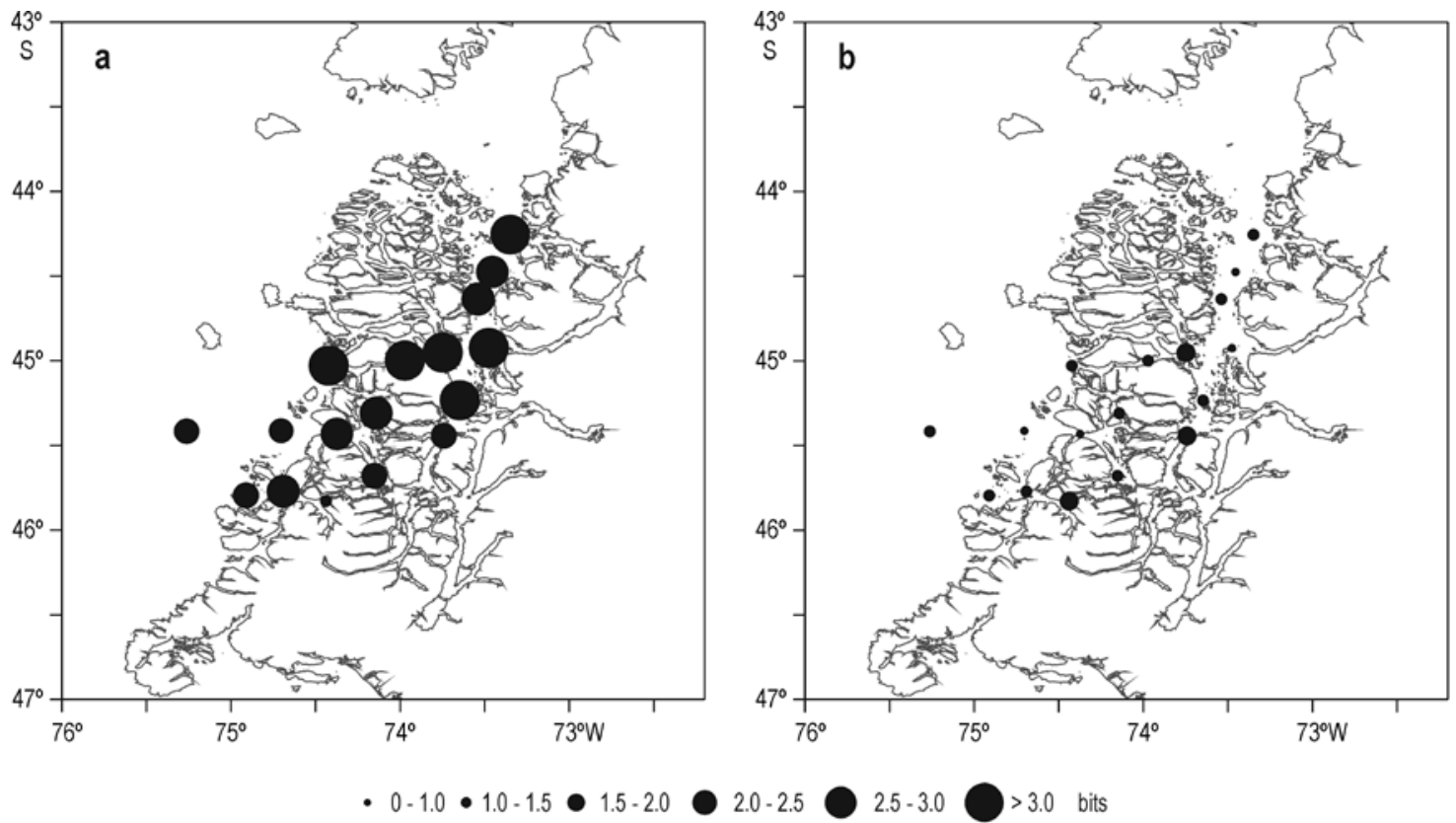

Figure 2. Diversity index in the study area. a) hydromedusae, b) siphonophores.

whereas the greatest densities $\left(>7,000\right.$ ind $\left.1000 \mathrm{~m}^{-3}\right)$ were found at the oceanic station and in the Moraleda and Pulluche channels. The siphonophores were more abundant than the hydromedusae, respectively constituting $59 \%$ and $41 \%$ of the total abundance. The eudoxid stage followed the same geographic distribution pattern as that of the nectophores and the largest aggregates were recorded in Moraleda Channel ( $>3,000$ ind $\left.1000 \mathrm{~m}^{-3}\right)$.

Of the dominant species, Sphaeronectes gracilis $(28.6 \%)$ was the most abundant, with wide geographic coverage (Fig. 3a). The greatest densities were recorded in Moraleda Channel, in the western mouth of the Darwin and Pulluche channels, and at the oceanic station (Sta. 87), where a maximum of 15,240 ind $1000 \mathrm{~m}^{-3}$ was observed. The lowest densities were recorded in the eastern sector of the oceanic channels.

Muggiaea atlantica (24.4\%) was the second most abundant species; its distribution was similar to that of $S$. gracilis (Fig. 3b). Nonetheless, its greatest densities were concentrated in the Moraleda Channel, where they reached a maximum of 9,724 ind $1000 \mathrm{~m}^{-3}$ at station 12. In the oceanic channels, low densities were found, particularly in the eastern sector.

Clytia simplex (9.6\%), the most abundant hydromedusa, presented wide geographic coverage in the study area (Fig. 3c). In spite of its very homogeneous distribution, as with the above-mentioned species, the greatest densities were recorded in Moraleda Channel (2,020 ind $1000 \mathrm{~m}^{-3}$ at station 9).

Proboscidactyla ornata (7.1\%), like the above species, was found widely distributed in the study area (Fig. 3d). The largest densities were obtained in interior waters, particularly to the south of the Meninea constriction-sill $\left(2,491\right.$ ind $1000 \mathrm{~m}^{-3}$ at station 31).

Amphogona apicata $(6.1 \%)$ presented wide geographic coverage but its abundance was concentrated in only two high-density cores: one at the entrance to Moraleda Channel and the other in Pulluche Channel, where a maximum of 5,549 ind $1000 \mathrm{~m}^{-3}$ was obtained (Sta. 75) (Fig. 3e).

Finally, Solmundella bitentaculata $(5.1 \%)$ was collected throughout the study area, but in very low densities (Fig. 3f). Only two high-concentration cores were found: one at the oceanic station (Sta. 87) and the other in the mouth of Moraleda Channel (Sta. 7).

\section{Vertical distribution}

The vertical distribution of cnidarians showed that 93\% of the specimens were distributed in the first $100 \mathrm{~m}$ depth. The specimens collected under 100 

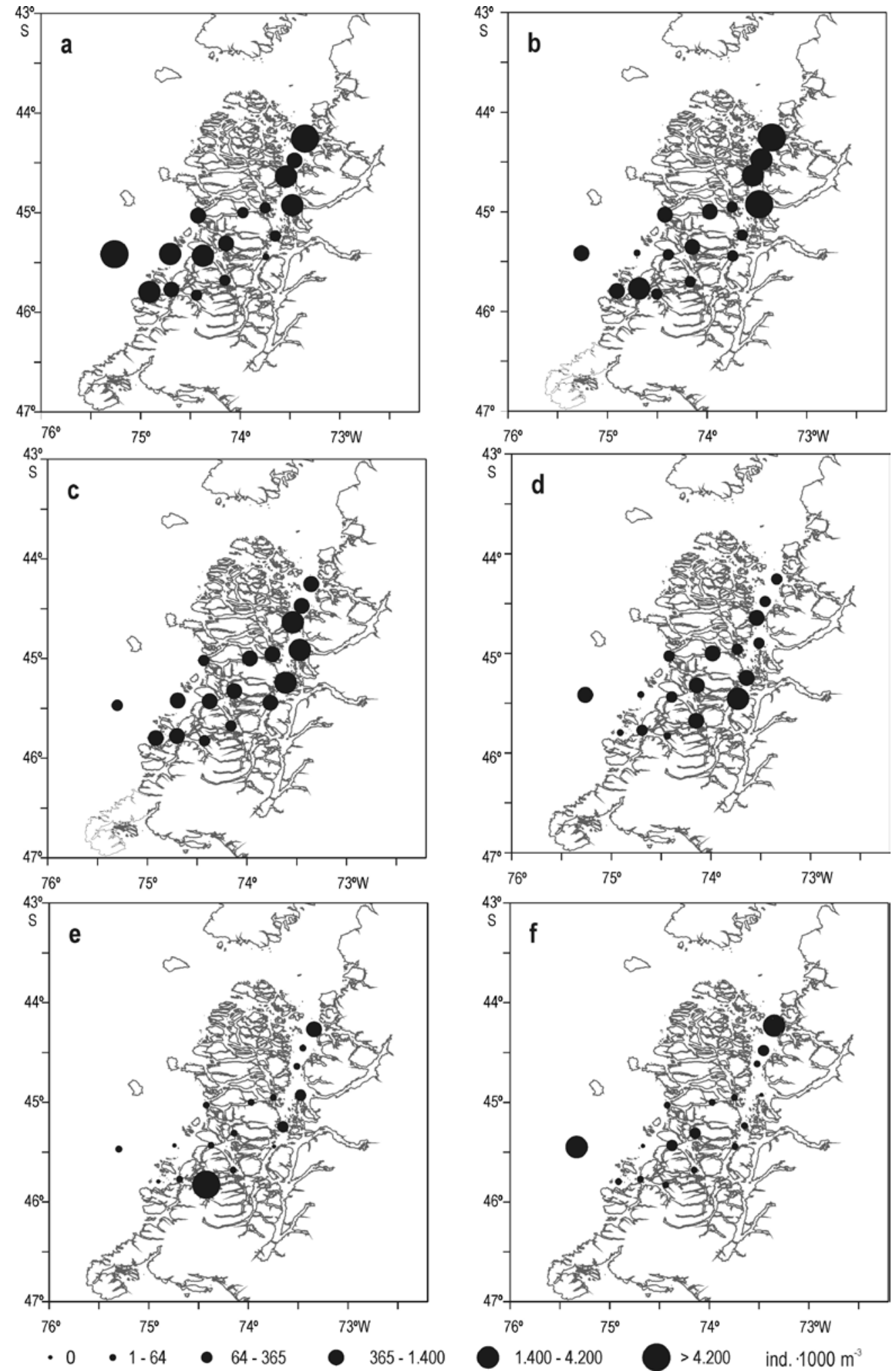

Figure 3. Spatial distribution of dominant species. a) Sphaeronectes gracilis, b) Muggiaea atlantica, c) Clytia simplex, d) Proboscidactyla ornata, e) Amphogona apicata, and f) Solmundella bitentaculata. 
$m$ depth were scarce and only caught in the deeper Moraleda and Darwin channels. The greatest abundance was recorded in the $20-50 \mathrm{~m}$ stratum $(40 \%)$; concentrations around $27 \%$ were recorded in both the $0-20$ and the $50-100 \mathrm{~m}$ strata.

Of the dominant species, Solmundella bitentaculata had the most superficial distribution $(0-20 \mathrm{~m})$, while Amphogona apicata was found at greater depths; most of the specimens were collected between 50 and $100 \mathrm{~m}$, and Sphaeronectes gracilis, Muggiaea atlantica, Clytia simplex, and Proboscidactyla ornata were collected in the subsurface stratum $(20-50 \mathrm{~m})$ (Fig. 4). The reproductive phase of the siphonophores, $60 \%$ of the $S$. gracilis eudoxids were collected in the upper stratum (0-20 m), being more superficial than the nectophores (Fig. 4e). The M. atlantica eudoxids, followed the same vertical distribution pattern as the nectophores (Fig. 4f).

\section{Correlation coefficient}

The results of the Pearson correlation analysis showed some significant associations $(\mathrm{p}<0.05)$ between the dominant species and temperature, salinity, and dissolved oxygen (Table 2). The abundances of Solmundella bitentaculata and Sphaeronectes gracilis correlated positively with salinity, whereas the abundance of Proboscidactyla ornata correlated negatively with salinity. On the other hand, the abundance of Clytia simplex correlated negatively with temperature and the dissolved oxygen concentration.
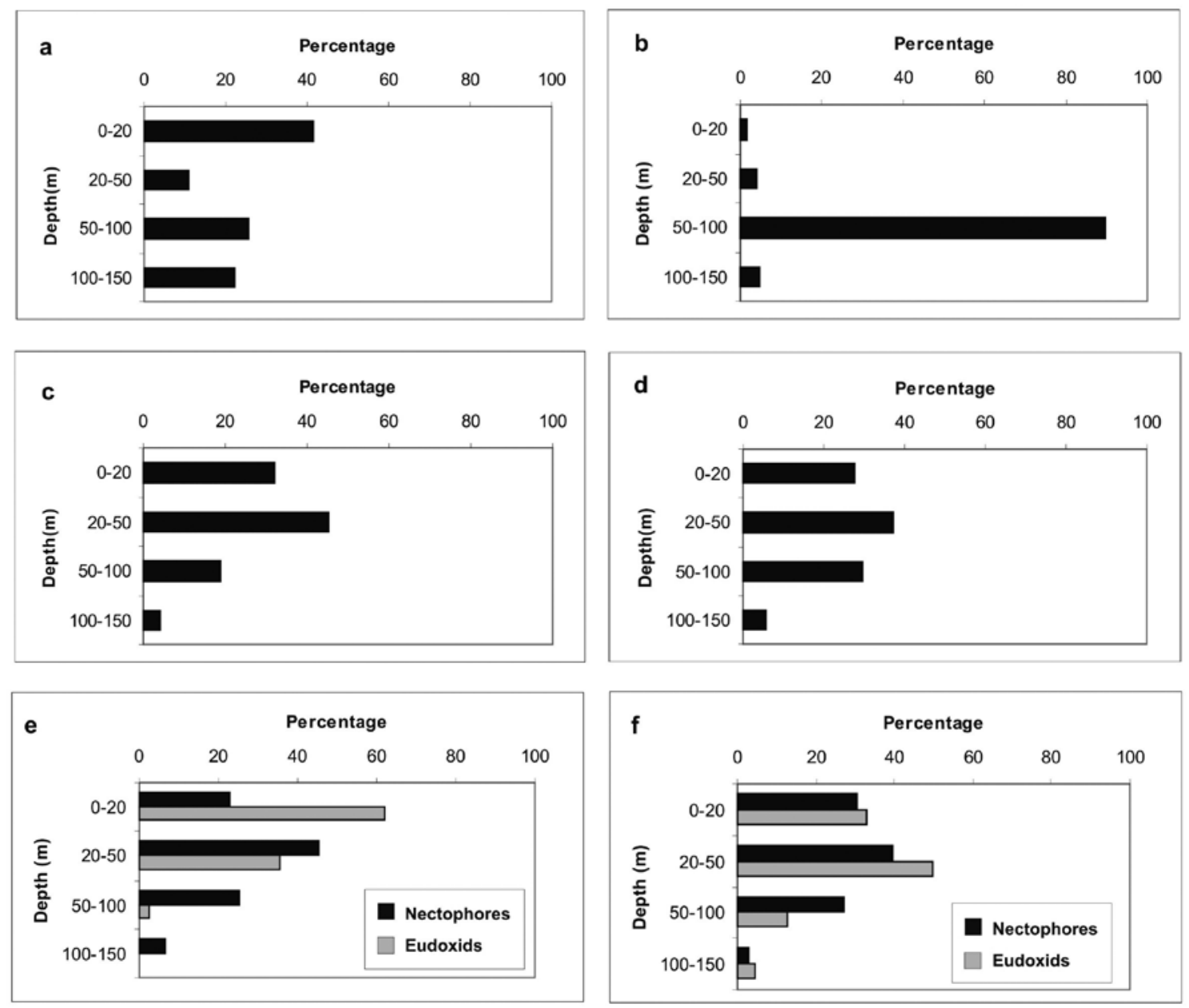

Figure 4. Vertical distribution of dominant species. a) Sphaeronectes gracilis, b) Muggiaea atlantica, c) Clytia simplex, d) Proboscidactyla ornata, e) Amphogona apicata, and f) Solmundella bitentaculata. 


\section{DISCUSSION}

The results obtained in the southern channels show that $86 \%$ of the species identified ( 31 species) had already been recorded in the vast southern channel and fjord zone that stretches from Puerto Montt to Cape Horn (Galea, 2006; Galea et al., 2007; Palma, 2006; Palma et al., 2007). Of the remaining 14\% (5 species), three hydromedusae (Gossea brachymera, Hybocodon unicus, Sarsia coccometra) and two siphonophore species (Rosacea cymbiformis, R. plicata) were recorded for the first time for the interior waters of southern Chile.

The geographic distribution of gelatinous organisms collected in the southern channels shows that most of the dominant species (Sphaeronectes gracilis, Muggiaea atlantica, Clytia simplex, Proboscidactyla ornata, Amphogona apicata, Solmundella bitentaculata) are common and abundant in subantarctic waters and have been caught in different regions of the Humboldt Current System (Kramp, 1966; Fagetti, 1973; Palma \& Rosales, 1995; Pagès et al., 2001; Palma \& Apablaza, 2004).

Furthermore, it can be indicated that the ecosystem of interior waters is made up of species from distinct biogeographic origins that can enter the interior zone through the Boca del Guafo and the oceanic channels (Tuamapu, King, Ninualac, Darwin, Pulluche). Therefore, species from Antarctic waters (i.e., Halopsis ocellata, Dimophyes arctica, Pyrostephos vanhoeffeni) coexist with species from subantarctic circumpolar waters (i.e., Amphogona apicata, Clytia simplex, Eudoxoides spiralis, Hydractinia borealis, H. minuta, Muggiaea atlantica, Lensia conoidea, Sphaeronectes fragilis, $S$. gracilis) and species with wide geographic or cosmopolitan distributions (i.e., Solmundella bitentaculata, Leuckartiara octona,
Proboscidactyla mutabilis, Rophalonema velatum).

$S$. gracilis was the dominant siphonophore, presenting wide geographic coverage. The greatest aggregates were recorded in Moraleda Channel, mainly in the areas receiving greater contributions of oceanic waters such as the oceanic station and the western sector of the Darwin and Pulluche channels. This was corroborated by the positive correlation values between this species and the weighted salinity averages in the water column (Pearson, $r=0.67$ ) (Table 2).

One species that was highly successful in the colonization of the interior waters was $M$. atlantica, the predominant siphonophore throughout the southern channel and fjord ecosystem from Puerto Montt to Cape Horn (Palma \& Silva, 2004; Palma, 2006). In the study area, this species presented an extensive geographic distribution, with high densities in the Moraleda Channel. This spatial distribution was due to the organisms' eurythermal and euryhaline nature (Palma \& Silva, 2004), which was confirmed by the absence of a correlation with temperature and salinity. This wide environmental tolerance was also reflected in its extensive bathymetric distribution, which showed important density cores up to $100 \mathrm{~m}$ depth, a behavior that was also observed in warmer waters, where its distribution can reach beyond 200 m depth (Gili \& Riera, 1987).

C. simplex was very abundant and presented wide spatial coverage, in agreement with the results from spring 2002, when its wide distribution was attributed to its euryhaline character (Palma et al., 2007). This species is found along the Chilean coast (Fagetti, 1973; Palma \& Rosales, 1995; Palma \& Apablaza, 2004) and is frequent in the interior southern channels and fjords (Pagès \& Orejas, 1999; Galea, 2007; Palma et al., 2007).

Table 2. Correlation values between the abundance of dominant species and the oceanographic variables. Significant values are indicated in bold $(\mathbf{p}<0.05)$.

\begin{tabular}{lcccccc}
\hline & $\begin{array}{c}\text { Muggiaea } \\
\text { atlantica }\end{array}$ & $\begin{array}{c}\text { Clytia } \\
\text { simplex }\end{array}$ & $\begin{array}{c}\text { Proboscidactyla } \\
\text { ornata }\end{array}$ & $\begin{array}{c}\text { Amphogona } \\
\text { apicata }\end{array}$ & $\begin{array}{c}\text { Solmundella } \\
\text { bitentaculata }\end{array}$ & $\begin{array}{c}\text { Sphaeronectes } \\
\text { gracilis }\end{array}$ \\
\hline Muggiaea atlantica & 1.00 & & & & & \\
Clytia simplex & 0.48 & 1.00 & & & & \\
Proboscidactyla ornata & -0.30 & -0.02 & 1.00 & & & \\
Amphogona apicata & -0.04 & -0.22 & -0.19 & 1.00 & & \\
Solmundella bitentaculata & 0.02 & -0.20 & 0.01 & -0.04 & 1.00 & \\
Sphaeronectes gracilis & 0.10 & -0.11 & -0.08 & -0.10 & $\mathbf{0 . 9 6}$ & 1.00 \\
Temperature & -0.37 & $\mathbf{- 0 . 5 7}$ & -0.22 & 0.07 & -0.39 & -0.33 \\
Salinity & 0.34 & 0.22 & $\mathbf{- 0 . 5 6}$ & 0.03 & $\mathbf{0 . 6 4}$ & $\mathbf{0 . 6 7}$ \\
Dissolved oxygen & -0.41 & $\mathbf{- 0 . 6 4}$ & 0.29 & 0.06 & -0.20 & -0.18 \\
\hline
\end{tabular}


P. ornata had the greatest densities in the interior waters, especially to the south of the Meninea constriction-sill. These aggregates were detected mainly in low-salinity zones $(<32.5)$, which was confirmed by their negative correlation with salinity (Pearson, $r=-0.56$ ).

The greatest densities of A. apicata were found at the ends of the Moraleda and Pulluche channels, showing a preference for waters with greater oceanic influence, as also reflected in the species' wide bathymetric distribution due to its oceanic and mesoplanktonic nature (Segura-Puertas, 1984; Pagès \& Orejas, 1999). A similar distribution pattern was found for S. bitentaculata, whose greatest densities were located mainly at the entrance to Moraleda Channel and the oceanic station, unlike the results obtained in the spring of 2002, when the maximum abundances were found in the eastern sector of the oceanic channels.

The high species diversity values estimated for the hydromedusae are consistent with the species richness recorded in the study area (29 species) and the low dominance values. On the other hand, the low diversity values estimated for the siphonophores are due to their low species richness ( 9 species) and elevated abundances of $S$. gracilis and M. atlantica, which constituted over $50 \%$ of the gelatinous organisms analyzed. The species richness of the medusae was three times higher than that of the siphonophores in the spring of 2003 (29:9); a similar proportion
(29:8) was found in the Magallanes Region (Pagès \& Orejas, 1999).

In general, the greatest cnidarian aggregates were recorded in the Moraleda Channel, indicating the existence of more favorable conditions for their retention. These aggregates occurred mainly in the subsurface stratum $(20-50 \mathrm{~m})$, suggesting that the individuals tend to avoid the surface waters $(0-20 \mathrm{~m})$ dominated by lower salinity estuarine waters flowing to the adjacent ocean through the diverse transversal channels (Fig. 5). In fact, Silva et al. (1998) indicated that the interior waters have a two-layer vertical saline structure, separated by a strong halocline centered at $25-30 \mathrm{~m}$ depth. The surface layer (0-25 m) was characterized by the presence of low salinity (2-31) corresponding to Estuarine Water (EW) and the deep layer by higher salinity (31-33) corresponding to Modified Subantarctic Water (MSAAW) distributed between 25 and $100 \mathrm{~m}$ depth. The MSAAW is originated by the mixing of higher salinity (>33-34) subantarctic waters that enter through the Boca del Guafo and the transversal channels (Tuamapu, King, Ninualac, Darwin, Pulluche) with the low salinity interior waters $(\mathrm{EW})$.

Previous studies indicate that high zooplankton biomass values are recorded in Moraleda Channel (Palma \& Rosales, 1997) and that this area, moreover, constitutes a favorable nursery area for eggs and larval stages for crustacean and fishes; oceanic species that enter through the Boca del Guafo co-exist with

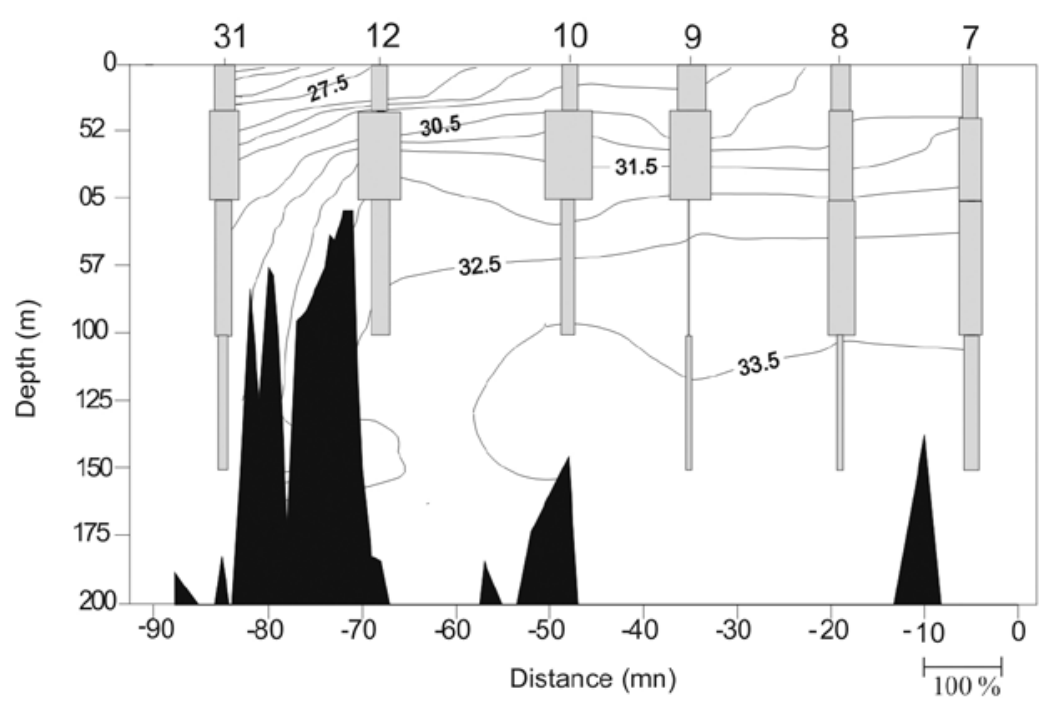

Figure 5. Vertical distribution of cnidarians in relation to the salinity in Moraleda Channel. 
species from the interior waters (Balbontín \& Bernal, 1997; Mujica \& Medina, 1997). This zooplanktonic abundance is sustained by the high concentrations of chlorophyll- $a\left(>5 \mathrm{mg} \cdot \mathrm{m}^{-3}\right)$ recorded in Moraleda Channel (Marín \& Delgado, 2004; Ramírez \& Pizarro, 2005). Moreover, Marín \& Delgado (2004) indicated that the low velocities recorded in Moraleda Channel increase the residence time, making this one of the areas most likely to sustain patches of high zooplankton concentrations in this southern region.

On the other hand, the zones with lower individual densities corresponded to the Ninualac,
Darwin, and Pulluche channels, where there is less water column stability due to the constant mixing of oceanic waters (saltier) that enter input from the west and mix with estuarine waters (low salinity) coming from the interior zone. This generates a noteworthy east-west salinity gradient (from lower to higher salinity), limited in its vertical distribution by a marked halocline. This gradient is reflected in the progressive increment of the abundance of gelatinous organisms towards the western end of the transversal channels, which was also observed in the spring of 2002 (Palma et al., 2007).

Table 3. Abundance ranges of hydromedusae collected in the same study area in springs 2002 (Palma et al., 2007) and 2003. - absent, + rare $\left(1-5\right.$ ind $\left.\cdot 1000 \mathrm{~m}^{-3}\right),++$ scarce $\left(5-50\right.$ ind $\left.\cdot 1000 \mathrm{~m}^{-3}\right),+++$ abundant $\left(50-500 \mathrm{ind} \cdot 1000 \mathrm{~m}^{-3}\right)$, ++++ very abundant $\left(>500\right.$ ind $\left.\cdot 1000 \mathrm{~m}^{-3}\right)$. The data of siphonophores are unplished.

\begin{tabular}{|c|c|c|}
\hline \multirow{2}{*}{ Species } & \multicolumn{2}{|c|}{ Spring } \\
\hline & 2002 & 2003 \\
\hline Aglaura hemistoma & + & - \\
\hline Amphinema rugosum & + & - \\
\hline Amphogona apicata & +++ & +++ \\
\hline Bougainvillia pyramidata & - & + \\
\hline Bougainvillia muscoides & - & +++ \\
\hline Bougainvillia sp. & +++ & +++ \\
\hline Calycopsis sp. & - & + \\
\hline Clytia simplex & ++++ & ++++ \\
\hline Cunina peregrina & + & + \\
\hline Cunina sp. & - & + \\
\hline Dipurena sp. & + & - \\
\hline Ectopleura dumortieri & + & +++ \\
\hline Euphysa aurata & ++ & +++ \\
\hline Gossea brachymera & - & + \\
\hline Halopsis ocellata & ++ & ++ \\
\hline Heterotiara minor & + & - \\
\hline Hydocodon unicus & - & +++ \\
\hline Hydractinia borealis & ++ & +++ \\
\hline Hydractinia minuta & ++++ & ++ \\
\hline Leuckartiara octona & ++ & ++ \\
\hline Liriope tetraphylla & ++ & +++ \\
\hline Obelia spp. & +++ & ++ \\
\hline Phialella quadrata & ++ & ++ \\
\hline Proboscidactyla mutabilis & + & ++ \\
\hline Proboscidactyla ornata & +++ & ++++ \\
\hline Proboscidactyla stellata & ++ & +++ \\
\hline Proboscidactyla sp. & - & + \\
\hline Rophalonema velatum & ++ & ++ \\
\hline Sarsia coccometra & - & + \\
\hline Sarsia eximia & + & + \\
\hline Solmundella bitentaculata & ++++ & +++ \\
\hline
\end{tabular}


Finally, only the results of the hydromedusae collected in the springs of 2002 (Palma et al., 2007) and 2003 were compared, since the siphonophore data from 2002 have not been published. In general, a scarce variability was observed both in the species composition as well as in the abundance of hydromedusae (Tables 1 and 3). In spring 2002, 23 species were determined as compared with the 27 identified in spring 2003. Of this total, 19 species were collected in both periods and had very similar abundance ranges (Table 3). In fact, three of the four most abundant species from each spring coincided (Amphogona apicata, Clytia simplex, Solmundella bitentaculata). This was also observed in the total abundance that increased slightly (from 159,864 to 161,912 ind $\cdot 1000 \mathrm{~m}^{-3}$ ) between 2002 and 2003. The most significant changes corresponded to the sharp drop in the abundance percentages of the dominant species determined in 2002: Hydractinia minuta (from 44.4 to $0.33 \%$ ), Clytia simplex (from 21.0 to $8.9 \%$ ), and Solmundella bitentaculata (from 14.5 to $4.9 \%$ ).

The results presented herein show a high similarity of fauna in the springs of 2002 and 2003 due to the similar environmental conditions in both seasonal periods. Therefore, it is likely that the strong fluctuations of abundance recorded in some dominant species were caused by changes in the trophic availability or in the intensity of the reproductive processes in the study area, especially in those species that contemplate asexual processes in their reproductive cycle, as is the case of numerous cnidarian species.

\section{ACKNOWLEDGEMENTS}

The authors would like to thank the Comite Oceanográfico Nacional for partial funding of this research (Project CONA-C9F/02-12); the commander and crew of the AGOR Vidal Gormaz of the Chilean Navy; Dr. Leonardo Castro, Universidad de Concepción, for facilitating the zooplankton samples; and Professor Nelson Silva, Pontificia Universidad Católica de Valparaíso, for providing the oceanographic data used herein.

\section{REFERENCIAS}

Balbontín, F. \& R. Bernal. 1997. Distribución y abundancia del ictioplancton en la zona austral de Chile. Cienc. Tecnol. Mar, 20: 155-163.
Bouillon, J. \& F. Boero. 2000. Phylogeny and classification of Hydroidomedusae. Synopsis of the families and genera of the Hydroidomedusae of the world, with a list of the worldwide species. Thalassia Salent., 24: 47-296.

Brodeur, R., H. Sugisaki \& G. Hunt Jr. 2002. Increases in jellyfish biomass in the Bering Sea: implications for the ecosystem. Mar. Ecol. Progr. Ser., 233: 89-103.

Fagetti, E. 1973. Medusas de aguas chilenas. Rev. Biol. Mar., Valparaíso, 15(1): 31-75.

Galea, H.R. 2006. Rediscovery and redescription of Hybocodon chilensis Hartlaub, 1995 (Cnidaria: Hydrozoa) from Comau Fjord, southern Chile. Zootaxa, 1258: 57-68.

Galea, H.R., V. Häussermann \& G. Forsterra. 2007. Hydrozoa, fjord Comau, Chile. Check List, 3(2): 159-167.

Gili, J.M. \& T. Riera. 1987. Distribución de las especies más frecuentes de sifonóforos calicóforos en la zona del Mediterráneo occidental. Invest. Pesq., 51(3): 323-338.

Kramp, P.L. 1966. A collection of Medusae from the coast of Chile. Vidensk. Meddr. Dansk Naturhist. Foren., 129: 1-38.

Kramp, P.L. 1968. The Hydromedusae of the Pacific and Indian Oceans. Sections II and III. Dana Rep., 72: 1-200.

Marín, V. \& L. Delgado. 2004. Determinación de áreas de retención de organismos planctónicos en la zona costera de la XI Región por medio de modelación numérica de la circulación y análisis de imágenes Seawifs. Crucero Cimar 9 Fiordos. Informes Preliminares, pp. 111-120.

Matsakis, S. \& R.J. Conover. 1991. Abundance and feeding of Medusae and their potential impact as predators on other zooplankton in Bedford Basin (Nova Scotia, Canada) during spring. Can. J. Fish. Aquat. Sci., 48: 1419-1430.

Mills, C. 2001. Jellyfish blooms: are populations increasing globally in response to changing ocean conditions? Hydrobiology, 451: 55-68.

Mujica, A. \& M. Medina. 1997. Larvas de crustáceos decápodos de los canales australes de Chile. Cienc. Tecnol. Mar, 20: 147-154.

Pagès, F. \& C. Orejas. 1999. Medusae, siphonophores and ctenophores of the Magellan region. Sci. Mar., 63(Suppl. 1): 51-57.

Pagès, F., H. González, M. Ramón, M. Sobarzo \& J.M. Gili. 2001. Gelatinous zooplankton assemblages associated with water masses in the Hum- 
boldt Current System and potential predatory impact by Bassia bassensis (Siphonophora: Calycophorae). Mar. Ecol. Progr. Ser., 210: 13-24.

Palma, S. 2006. Distribución y abundancia de zooplancton en canales y fiordos australes. In: N. Silva \& S. Palma (eds.). Avances en el conocimiento oceanográfico de las aguas interiores chilenas, Puerto Montt a cabo de Hornos. Comité Oceanográfico Nacional-Pontificia Universidad Católica de Valparaíso, Valparaíso, pp. 107-113.

Palma, S. \& P. Apablaza. 2004. Abundancia estacional y distribución vertical del zooplancton gelatinoso carnívoro en un área de surgencia en el norte del Sistema de la Corriente de Humboldt. Invest. Mar., Valparaíso, 32(1): 49-70.

Palma, S. \& S. Rosales. 1995. Composición, abundancia y distribución estacional del macrozooplancton de la bahía de Valparaíso. Invest. Mar., Valparaíso, 23: 49-66.

Palma, S. \& S. Rosales. 1997. Sifonóforos epipelágicos de los canales australes de Chile $\left(41^{\circ} 30^{`}-46^{\circ} 40^{`} \mathrm{~S}\right)$. Cienc. Tecnol. Mar, 20: 125-146.

Palma, S. \& N. Silva. 2004. Distribution of siphonophores, chaetognaths and euphausiids and oceanographic conditions in the fjords and channels of southern Chile. Deep-Sea Res. II, 51: 513-535.
Palma, S., P. Apablaza \& N. Silva. 2007. Hydromedusae (Cnidaria) of the Chilean southern channels (from the Corcovado Gulf to the Pulluche-Chacabuco Channels). Sci. Mar., 71(1): 65-74.

Purcell, J.E. 1997. Pelagic cnidarians and ctenophores as predators: selective predation, feeding rates, and effects on prey populations. Ann. Inst. Océanogr., Paris, 73(2): 125-137.

Ramírez, B. \& E. Pizarro. 2005. Distribución de clorofila-a y feopigmentos en los canales australes chilenos comprendidos entre Puerto Montt y la laguna San Rafael, Chile. Cienc. Tecnol. Mar, 28(1): 45-62.

Segura-Puertas, L. 1984. Morfología, sistemática y zoogeografía de las medusas (Cnidaria, Hydrozoa y Schyphozoa) del Pacífico tropical oriental. Publicación Especial. Instituto de Ciencias del Mar y Limnología, UNAM: 1-320.

Servicio Nacional de Pesca (SERNAPESCA). 2007. Anuario estadístico de pesca. (http//www.sernapesca.cl). Revised: 20 Juin 2007.

Silva, N., C. Calvete \& H. Sievers. 1998. Masas de agua y circulación general para algunos canales australes entre Puerto Montt y Laguna San Rafael (Crucero Cimar-Fiordo 1). Cienc. Tecnol. Mar, 21: 17-48.

Totton, A. 1965. A synopsis of the Siphonophora. Trust. Brit. Mus. Nat. Hist., London, 230 pp. 